\title{
Museology opens opportunities: A new generation of museums
}

\section{Susanna Pettersson}

Megatrend reports all tell us the same message. Technology will change everything, work will not be the same, and people will have more leisure time. They'll need motivating ways to build up their wellbeing and contribute to society. This is a window of opportunities for museums, archives and visual art organisations as well as professionals working for them. Therefore, the role of museology is crucial now -- and even more so in the future.

Based on the scenario above, it's not exaggerated to state that museums and archives are more important today than ever before. Firstly, when traditional work changes, our relation to time will change, too. People will have to find alternative targets for allocating their time. Services provided by the culture industries will be among the many options. Museums and archives provide meaningful encounters and alternative ways to spend time. As sociologists have pointed out, visiting an exhibition can make you feel elevated, almost like a better person.

Secondly, memory organisations such as museums and archives form the backbone of our collective identity. In the world of a disrupted media environment, we no longer share the same facts, let alone values. The topics that occupy our minds include issues that can be increasingly hard to handle: they range from climate change to migration, natural disasters, terrorism, intolerable poverty, unbearable political decisions and the threat of nuclear war. Worlds are drifting apart, and the new class divider is the information gap: our capacity to cope with the excessive amount of knowledge. In a situation like this, we need tools to experience, analyse and understand the world around us.

Art and culture at large build our cultural DNA: they can help us to understand who we are. Art and culture organisations, in turn, provide the physical platform for research, exhibitions and displays, projects and try-outs. They are safe environments in which to discuss even disturbing issues and wicked problems. Archives and collections are needed to safeguard the documents, objects and works that will pass the message on to future generations.

Therefore, we need better museum professionals than ever before. They have to be curious and alert, they have to master the contents, and they have to be well connected with the rest of the world. This is when museology steps into the picture.

\section{Museology COUNTS}

Museology represents lots of unleashed potential within the museum field. It's a method and a tool. The better understanding that museum professionals have of museology, the better they can run museums for the benefit of the public. In Finland, there's a growing tendency to visit museums. In 2017, the estimated number of visits is 7 million, with the country's population being 5.5 million. 
Collection management and research, exhibitions, public programmes, communication and marketing, fundraising, museum shops and restaurants and the design of public spaces all fall into the scope of museological interest. Museology is also helpful when analysing the potential of the museums in the existing environment, whether it be political, economical, social, technical, legal, environmental or cultural.

As a discipline, museology encourages museum professionals to be more analytical and even more demanding in what they do, to whom and why. Therefore, ambitious collaboration between museums and universities is more than welcome.

Museums should invest in collaborative research programmes, providing opportunities for students, interns and research groups to participate in problem-solving, concept development and real-life projects. The challenge is to guarantee the tutoring and resources, and ensure that collaboration, once started, has a proper life cycle and preferably a long-term plan.

Museums and universities should also invest together in publishing the results of collaborations in order to ensure that the outcomes of the work can be shared within the larger museum and academic community. Web journals, scientific publications, conferences and seminars provide natural platforms for such initiatives.

One concrete example of this is the scientific online journal FNG Research, established in 2015 by the Finnish National Gallery, Helsinki. It encourages academics, students and museum professionals to publish both peer-reviewed articles and lighter presentations of projects related to the contents of the Finnish National Gallery.

Another important initiative is a research- oriented internship programme for art or cultural history students, including museology. The programme, which started in 2017, has two aims. The Finnish National Gallery wishes to enhance the study of its collections including art works, archives, and objects. At the same time the museum wishes to support students who choose to write master's level theses on subjects based on physical collections and objects, archive material and data. Both win: the student gets tutoring from the museum and the museum builds a network of researchoriented young scholars, the future creators of the museum.

In doing so, the Finnish National Gallery aims to raise new interest in research topics based on its resources and collections. It also wishes to be an active and innovative partner in collaborating with the academic scene in reinforcing humanistic values and the importance of understanding the world and human culture by creating new, meaningful and relevant knowledge.

\section{BUILDING FOR THE FUTURE}

The future of the museum profession and museology as a discipline is about sharing knowledge and expertise. It is also about visionary decisions and courage.

Today's world is noisier and busier than (perhaps) ever before. The attention span of a human being has been compared to that of a goldfish. We're offered numerous ways to master our thoughts and wellbeing, to nurture our need for focus and silence. This profession carries the responsibility of making parts of the excessive information, or noise, discernible. The amount of visitors is constantly increasing, and keeping in mind the future scenarios related to people with more free time, museums will become important 
136 hubs for people for gathering together and elaborating their thoughts around both topical issues and plentiful narratives of history.

The way of working in museums will move towards clouds of competencies and professional bridge building. Instead of having all possible areas of expertise within existing organisations, both on the national and international level, we might collect teams of specialists around projects. We might want to involve audiences in the production of knowledge, as many organisations have already been doing for quite some time. And we surely want to question our prevailing practices and methods of working and develop relationships with other sectors of society. These are also reasons why we need more professionals with training in museology.

Competence in museology and mobility of professionals can be regarded as one of the keys to success for any museum or archive in the future. Consequently, one could say that the exchange of expertise, flexibility, trust and networks are the building blocks of our future. The more we share within the international museum community, the better.
The work and methods in museums and archives are constantly changing and developing. That said, there's still one thing that won't change no matter what the media or spaces of display are: the human need to encounter the authentic, original object, document or an artwork. Museums and archives continue to be the places to go for inspiration and contemplation. They offer a gateway for slowing down or getting really high.

\section{Susanna Pettersson, $P h D$}

Museum Director, Ateneum Art Museum I

Finnish National Gallery

Adjunct Professor, University of Jyväskylä

Associate Professor, Reinwardt Academy

Ateneum Art Museum/Finnish

National Gallery

Kaivokatu 2,

FI-00100 Helsinki, Finland 